\title{
Effects of feeding strategy on milk production, reproduction, pasture utilization, and economics of autumn-calving dairy cows in eastern North Carolina
}

\author{
R. E. Vibart, ${ }^{\star}$ S. P. Washburn, $\dagger^{1}$ J. T. Green Jr.,‡ G. A. Benson,§ C. M. Williams,† D. Pacheco, ${ }^{\star}$ \\ and N. Lopez-Villalobos\# \\ ${ }^{*}$ AgResearch Limited, Grasslands Research Centre, Palmerston North 4442, New Zealand \\ †Department of Animal Science, \\ $\ddagger$ Department of Crop Science, and \\ $\S$ Department of Agricultural and Resource Economics, North Carolina State University, Raleigh 27695 \\ \#Institute of Veterinary, Animal and Biomedical Sciences, Massey University, Palmerston North 4442, New Zealand
}

\section{ABSTRACT}

A balance among stocking rate (SR), pasture management, and supplementary feeding is required to optimize overall farm performance and profitability in pasture-based dairying. Beginning in September 2003, a seasonal, autumn-calving, pasture-based farming system was established to address the effects of feeding strategy (FS; i.e., a unique combination of stocking and supplementation rate) on productive, reproductive, and economic performance of lactating herds over $3 \mathrm{yr}$. Eighty lactating cows ( $1 / 3$ Holsteins, $1 / 3$ Jerseys, and $1 / 3$ crosses of those breeds) were randomly assigned to either a lesser stocking, lesser supplementation group [LSR; 2.2 cows $/$ ha, $6.3 \mathrm{~kg}$ of dry matter (DM) of a corn-based concentrate consumed daily, $\mathrm{n}=40$ ] or a greater stocking, greater supplementation group (HSR; 3.3 cows $/$ ha, $9.2 \mathrm{~kg}$ of DM of a corn-based concentrate consumed daily, $\mathrm{n}=40$ ). Pasture/forage crop rotations included annual ryegrass and sorghum-Sudan (50\%), annual ryegrass and bermudagrass (20\%), and a tall fescue-white clover pasture (30\%). Pre- and postgrazing herbage mass values and grazing intervals $(3,347 \pm$ $255.8 \mathrm{~kg}$ of DM/ha, $1,861 \pm 160.6 \mathrm{~kg}$ of DM/ha, $23.6 \pm$ $1.9 \mathrm{~d}$ ) did not differ between FS. The nutritive value of fresh and conserved forages was similar between feeding strategies, except for acid detergent fiber in freshly grazed bermudagrass (29.6 vs. $26.3 \%$ of DM for LSR and HSR, respectively). Cows on HSR tended to spend more time on an adjacent feeding area where conserved forages were offered (85 vs. $61 \mathrm{~d} / \mathrm{yr}$ ) as opposed to grazing paddocks (204 vs. 228 d/yr). Lactation performance was greater for HSR; cows on HSR produced $10.8 \%$ more milk fat and $6.3 \%$ more milk protein than

Received July 21, 2011.

Accepted October 24, 2011.

${ }^{1}$ Corresponding author: steve_washburn@ncsu.edu cows on LSR. Holstein cows produced the greatest amounts of mature-equivalent milk, but did not differ from crossbred cows in terms of energy-corrected milk, and mature-equivalent fat and protein yields. Reproductive efficiency did not differ among feeding strategy, but breed differences were observed; conception rates at first and all services, as well as pregnancy rates, were greater for Jersey and crossbred cows compared with Holsteins. The greater stocking rate required additional supplemental concentrate and time away from grazing paddocks, but reproductive efficiency was similar and overall lactation performance was greater. The greater stocking rate resulted in increased productivity and greater income over feed costs per unit of land.

Key words: stocking rate, supplementation, grazing, milk production

\section{INTRODUCTION}

Renewed interest in intensive grazing dairy production systems has been reported globally (Dillon et al., 2005; Macdonald et al., 2008; Baudracco et al., 2010), including in the United States (White et al., 2002; Bargo et al., 2003; Fike et al., 2003). The reasons behind the renewed interest in pasture-based dairying include reduced milk prices, increased production costs, and perceived animal welfare and environmental benefits from these systems relative to confinement-type systems. Existing knowledge of profitability and environmental impact is limited but suggests that pasturebased dairies in the United States can be profitable with less manure storage and lower capital investment than confinement-type systems.

Research data on grazing dairy systems in the southeastern United States are limited. The region provides some unique challenges related to climate and soils that create the need to combine cool- and warm-season grazing species in the grazing rotation (White et al., 
2002; Fike et al., 2003). This, in turn, provides a broad range and dynamic changes in nutritive value of forages throughout the lactating season (Fontaneli et al., 2005), in addition to the inherent difficulty in quantifying herbage intake from pasture and formulating a balanced diet accordingly. Warm-season forage species that are adapted to the region (i.e., bermudagrass; Cynodon dactylon) often have lesser nutritive value than cool-season forages, but can provide grazing during late spring, summer, and early autumn (Fike et al., 2003). Conversely, better quality cool-season species such as perennial ryegrass (Lolium perenne) may not survive intensive grazing under the extreme summer temperatures in the region (Abberton et al., 2008).

Supplemental energy is required to express genetic potential for milk production in grazing systems. Substantial evidence from research studies conducted in the eastern United States comparing dairy confinement systems with pasture-based systems (with or without supplementation) consistently shows reduced DMI, milk production, and BCS for pasture-based dairying (Kolver and Muller, 1998; Soriano et al., 2001; Bargo et al., 2002; White et al., 2002; Fontaneli et al., 2005). Few long-term, full-lactation comparative studies of pasture and confinement systems have been conducted in the region (White et al., 2002; Fontaneli et al., 2005). In Florida, milk production from cows in confinement was $19 \%$ greater than those on pasture, but income over feed costs was similar for all 3 management systems tested (Fontaneli et al., 2005). In North Carolina, pasture-based dairying was competitive in terms of profitability (White et al., 2002) and reproductive performance (Washburn et al., 2002) while providing a more sustainable manure-management system (White et al., 2001) compared with a confinement-type system. Cows on pasture supplemented daily with a corn-based concentrate produced $11 \%$ less milk, and had lower BCS and lesser BW than cows fed a nutritionally balanced TMR, but cows exhibited fewer clinical cases of mastitis (Washburn et al., 2002).

Questions remain, however, as to whether different grazing feeding strategies (i.e., combinations of stocking and supplementation rates, with grazing species adapted to the region) affect profitability and sustainability. White et al. (2002) recommended the examination of the effects of stocking rate (SR) on economic and lactation performance measures in multiple year comparisons. Previously, King (1997) conducted a simulation based on pasture data from White et al. (2002), concluded that greater SR should be more profitable under the economic conditions existing at that time, and recommended that applied research be conducted on this issue. However, holistic assessments of such management systems for the region are still lacking. The objective of this trial was to examine the effects of 2 feeding strategies (FS; a unique combination of stocking and supplementation rates) on production, reproduction, pasture utilization, and economics across $3 \mathrm{yr}$ for lactating herds that included Holsteins, Jerseys, and crossbreds. Preliminary findings (Benson et al., 2006; Washburn et al., 2006) and partial reports (Vibart et al., 2009a,b) from this 3-yr trial have been reported elsewhere.

\section{MATERIALS AND METHODS}

\section{Research Site}

This trial was conducted at the Cherry Research Farm dairy unit, Center for Environmental Farming Systems (CEFS), Goldsboro, North Carolina, from October 2003 to August 2006. Topographically, the research site lies in the Mid-Atlantic Coastal Plain; the Dairy Unit at CEFS $\left(35^{\circ} 38^{\prime} \mathrm{N}, 78^{\circ} 05^{\prime} \mathrm{W}, 24 \mathrm{~m}\right.$ above sea level) is located in the Neuse River Basin. The soils consist of ocean and fluvial-deposited sediments of sand, silt, and clay. Predominant soils differ based on topography (i.e., upland and river valleys), drainage class, and the textural class of the original sediments (Scott et al., 2003). Soils are moderately acid and strongly leached, with relatively low chemical fertility and humic matter contents (Barnhill, 1974).

Pastures were established primarily on soils belonging to the series Lakeland (thermic, typic quartzipsamments), Pantego (fine-loamy, thermic umbric paleaquults), and Kenansville (loamy, thermic arenic hapludults), accounting for almost $60 \%$ of the total pasture area. Warm summers and moderate winters are prevalent in the Coastal Plain of North Carolina. At a $50 \%$ probability level, the $0^{\circ} \mathrm{C}$ freeze-free growing season in Goldsboro is about $216 \mathrm{~d}$. Compared with long-term annual data (mean air temperature $16.7^{\circ} \mathrm{C}$, mean precipitation $1,198 \mathrm{~mm} ; 1970-2002)$, mean air temperature (at a 2-m height) was slightly lower $\left(15.7\right.$ and $15.8^{\circ} \mathrm{C}$ for 2004 and 2005, respectively), and precipitation (909.6 and $970.8 \mathrm{~mm}$ ) was 24 and $19 \%$ lower, respectively (State Climate Office of North Carolina, NC CRONOS Database, data retrieval from Goldsboro, NC).

\section{Experimental Design, Cows, and Treatments}

A seasonal, autumn-calving, pasture-based system was established to address the effects of feeding strategy on productive, reproductive, and economic performance. Because the purpose of this research was to evaluate alternative feeding strategies with multiple components and multiple effects, the specific research procedures were designed from a farming systems perspective. The 
pros and cons of this approach are discussed in Welsh and Ingram (1997). Management decision rules were applied uniformly among treatments, with the same paddocks allocated to the same SR groups over the 3 -yr period.

To avoid milking during the hottest months (i.e., July through September) and to provide a rebreeding window with acceptable conception rates, an autumncalving system was established similar to that of White et al. (2002). Eighty lactating cows, including Holsteins $(\mathbf{H})$, Jerseys $(\mathbf{J})$, and crossbreds $(\mathbf{C})$, were randomly assigned to 1 of 2 SR groups in a closed farmlet system design. Stocking rate was defined as the relationship between the number of lactating cows and the grazing area used to support them over an entire lactation. Cows were assigned to either a lesser stocking, lesser supplementation rate (LSR) group, initially formulated at $2.47 \mathrm{cows} / \mathrm{ha}$, or a greater stocking, greater supplementation rate (HSR) group, initially formulated at 3.70 cows/ha. Over the 3 lactations, actual SR ranged from 1.95 to 2.26 cows/ha for the LSR group, and from 2.87 to 3.35 cows/ha for the HSR group, depending on cow availability and length of the calving season; mean SR were 2.2 and 3.2 cows for the LSR and HSR groups, respectively.

Each group was originally planned to consist of 40 cows comprising $13 \mathrm{H}, 13 \mathrm{~J}$, and $14 \mathrm{C}$ cows, but due to availability of cows the average percentages by breed were $40.8 \% \mathrm{H}, 28.9 \% \mathrm{~J}$, and $30.3 \% \mathrm{C}$ cows across the $2 \mathrm{FS}$. The $\mathrm{C}$ cows varied from $3 / 4 \mathrm{H}$ to $3 / 4 \mathrm{~J}$; mean percentage of Holstein genetics was 53.0, 49.5, and $51.4 \%$ for 2003, 2004, and 2005 calving seasons, respectively. Although total cow numbers per treatment group varied, the relative proportion of breeds was similar between treatment groups across all $3 \mathrm{yr}$. Cows were blocked by milk yield, parity, and breed, and were assigned at random to one of the groups shortly after calving. Calving seasons were from September to December each year and were $119 \mathrm{~d}$ in $2003,84 \mathrm{~d}$ in 2004, and $94 \mathrm{~d}$ in 2005. Typically, herbage from pasture was available throughout the autumn, spring, and early summer, with limited amounts available during winter (Figure 1). Lactation recordings commenced when each group had at least 10 lactating cows: October 28, 2003; October 18, 2004; and October 29, 2005, for years 2003-2004 (yr 1), 2004-2005 (yr 2), and 2005-2006 (yr 3 ), respectively. Corresponding lactations ended on August 12, 2004; August 15, 2005; and August 2, 2006, resulting in lactation lengths of 288,302 , and $278 \mathrm{~d}$, respectively.

Cows had access to a fresh allocation of pasture twice daily (after each milking), and had access to fresh water in every paddock. A corn-based concentrate was offered daily in proportional amounts relative to SR: (mean $\pm \mathrm{SE}$ ) $6.30 \pm 0.08$ and $9.16 \pm 0.10 \mathrm{~kg}$ of DM/ cow for LSR and HSR, respectively. Mean composition of the concentrate mix offered (DM basis) was $72.6 \%$ ground corn, $21.3 \%$ whole cottonseed, $4.1 \%$ soybean meal, $0.2 \%$ vitamin mix (McNess, Freeport, IL, plus a mineral mix); chemical composition of the concentrate mix was $89.3 \% \mathrm{DM}, 13.3 \% \mathrm{CP}, 11.4 \% \mathrm{ADF}$, and 8.1 MJ of $\mathrm{NE}_{\mathrm{L}} / \mathrm{kg}$ of DM (North Carolina Forage Testing Laboratory, North Carolina Department of Agriculture, Raleigh). Ingredients in the mix and the amounts offered daily, however, varied according to pasture availability and nutritive value. The relative proportions of the amount of feed offered to cows on LSR and HSR were maintained throughout the 3 -yr period.

\section{Pasture Layout}

Farmlets were established and balanced for soil type, forage species, geographic location, and walking distance to the milking parlor. Thirty-two hectares (27.1
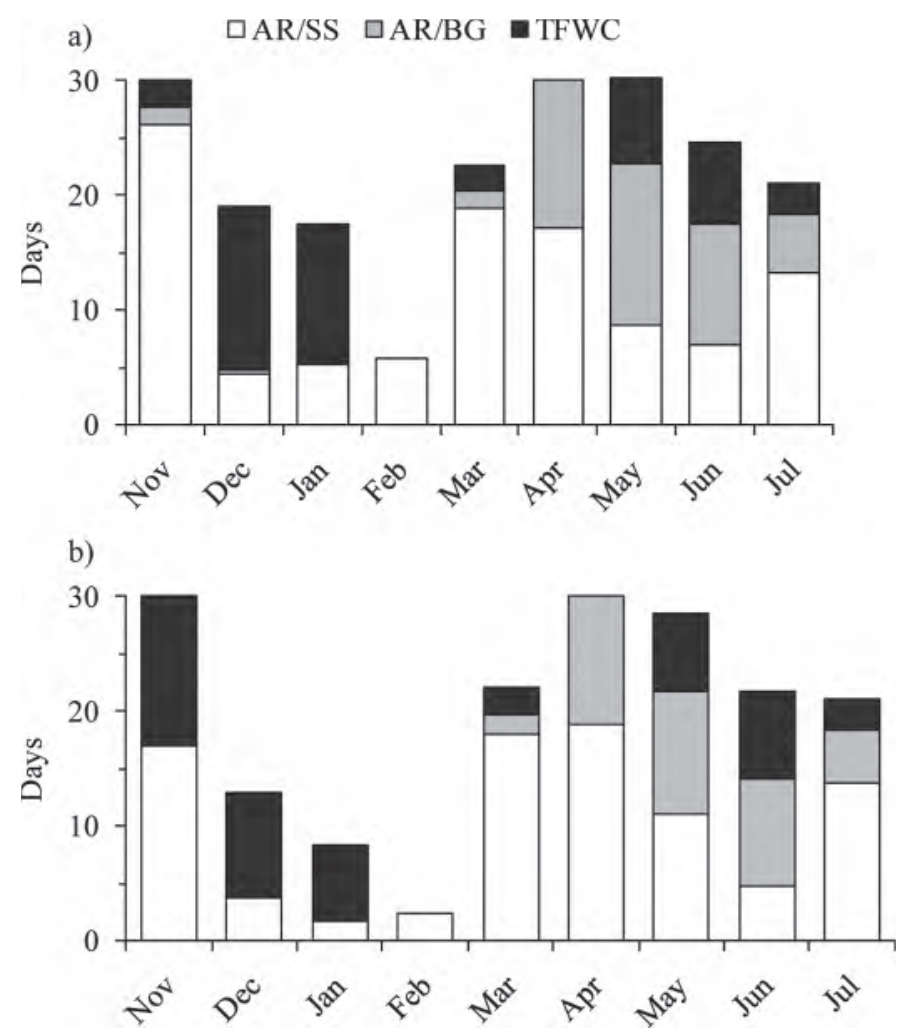

Figure 1. Grazing days per month on each forage/crop rotation, including an annual ryegrass/sorghum-Sudan rotation (AR/SS; white), an annual ryegrass/bermudagrass rotation (AR/BG; gray), and a tall fescue/white clover pasture (TFWC; black) from cows stocked at either (a) a lesser stocking rate, lesser supplementation rate (LSR; 2.2 cows/ha) or (b) a greater stocking rate, greater supplementation rate (HSR; 3.2 cows/ha). For days or parts of days not covered by those allocations, cows were in shade paddocks (late spring, summer) or in adjacent feeding areas (winter and summer). 
ha in rotationally grazed pasture) were allocated to SR groups. The pasture system was designed to supply as much of the nutritional requirements of the lactating animals as possible without compromising pasture productivity. Pasture/forage crop rotations were set up proportionately based on soil types and forage species on 16.2 ha for the LSR group and on 10.9 ha for the HSR group. Pasture/forage crop rotations included annual ryegrass (Lolium multiflorum Lam. 'Marshall') and sorghum Sudan (Sorghum bicolor [L.] Moench) (50\% of grazing area), annual ryegrass overseeded on bermudagrass (Cynodon dactylon [L.] Pers.) (20\% of grazing area), and an improved tall fescue [Lolium arundinaceum (Schreb.) S.J. Darbyshire]-white clover (Trifolium repens L.) pasture (30\% of grazing area). Annual ryegrass (11.3 ha allocated to LSR and 7.7 ha allocated to HSR) was grown either in a conventional tillage rotation with brown midrib (BMR) 'Haymaster' sorghum-Sudan hybrid (AR/SS; 13.5 ha) or sodseeded without the use of herbicide into an established 'Coastal' bermudagrass pasture (AR/BG; 5.5 ha). The perennial, cool-season pasture consisted of 'Jesup' tall fescue with a novel-type endophyte (AR542, marketed as MaxQ, Pennington Seed Inc., Madison, GA) and 'Will' white clover (TFWC; 8.2 ha). The planting and fertilization schedule for each pasture rotation component is presented in Table 1.

A bermudagrass stand (Tifton 44) established in 1996 was used for the AR/BG rotation (3.3 ha allocated to LSR and 2.2 ha allocated to HSR). During the summer, those paddocks received about $16 \mathrm{~kg}$ of $\mathrm{N} /$ ha after each grazing, totaling about $59 \mathrm{~kg}$ of $\mathrm{N} /$ ha throughout the summer grazing period (bermudagrass production con- tinued for longer than that of the sorghum-Sudan hybrid). Paddocks in tall fescue (4.9 ha allocated to LSR and 3.3 ha allocated to HSR) were established in 1999, whereas the white clover was added in February 2000 by over-sowing the stand with the use of a spinner, at a seeding rate of $2.3 \mathrm{~kg} / \mathrm{ha}$. An additional over-seeding of white clover was made in February 2004. This perennial pasture was used primarily to provide grazing during the periods when cows were not lactating (late summer and early autumn), and as stockpiled forage in late November and December to extend the autumn/early winter grazing season, and briefly during the transition period from cool- (AR) to warm-season (BG and SS) pastures (late May and June).

\section{Pasture Management}

The 3 pasture rotations described above were used to provide high-nutritive value grazing throughout most of the year. A typical grazing rotation for the autumn-calving cows included grazing a combination of winter and summer annuals, along with winter and summer perennials (Figure 1). Cows grazed the cool-season pastures in the autumn, starting with the annual ryegrass from the conventional-tillage rotation, followed by either annual ryegrass from the no-till rotation or the tall fescue/white clover pasture, the latter allocated primarily as stockpiled growth. In the spring, cows grazed a similar sequence, prioritizing the use of conventionally seeded annual ryegrass, followed by annual ryegrass from the no-till rotation. As the spring season progressed, cows on pasture transitioned from cool- to warm-season pastures in late May and early

Table 1. Occupation, planting, and fertilization scheme of annual, cool-season (annual ryegrass, AR) and warm-season (sorghum-Sudan hybrid, SS) forages during a 3 -yr trial ${ }^{1}$

\begin{tabular}{|c|c|c|c|}
\hline Species and hectares & Year 1 & Year 2 & Year 3 \\
\hline \multicolumn{4}{|l|}{ Annual ryegrass ${ }^{2}$ (13.5 ha) } \\
\hline Planting date & Oct. 3, 2003 & Sep. 7, 2004 & Sep. 20, 2005 \\
\hline Seeding rate, kg/ha & 11.4 & 11.4 & 11.4 \\
\hline First day of grazing & Nov. 8, 2003 & Oct. 18,2004 & Oct. 29,2005 \\
\hline Fertilization rate, $\mathrm{kg}$ of $\mathrm{N} / \mathrm{ha}$ & 98.1 & 78.5 & 86.9 \\
\hline \multicolumn{4}{|l|}{ Annual ryegrass ${ }^{3}$ (5.5 ha) } \\
\hline Planting date & Oct. 12,2003 & Sep. 12, 2004 & Sep. 10, 2005 \\
\hline Seeding rate, kg/ha & 11.4 & 11.4 & 11.4 \\
\hline First day of grazing & Mar. 29, 2004 & Mar. 19, 2005 & Oct. 26,2005 \\
\hline Fertilization rate, $\mathrm{kg}$ of $\mathrm{N} / \mathrm{ha}$ & 98.1 & 78.5 & 86.9 \\
\hline \multicolumn{4}{|l|}{ Sorghum-Sudan hybrid ${ }^{4}$ (13.5 ha) } \\
\hline Planting date & May 21, 2004 & May 23, 2005 & May 10, 2006 \\
\hline Seeding rate, $\mathrm{kg} / \mathrm{ha}$ & 44.8 & 44.8 & 44.8 \\
\hline First day of grazing & June 15, 2004 & July 1, 2005 & June 12, 2006 \\
\hline Fertilization rate, $\mathrm{kg}$ of $\mathrm{N} / \mathrm{ha}$ & 44.9 & 44.9 & 56.1 \\
\hline
\end{tabular}

\footnotetext{
${ }^{1}$ Year $1=2003-2004$; year $2=2004-2005$; year $3=2005-2006$.

${ }^{2}$ Annual ryegrass as a component of the annual ryegrass/sorghum-Sudan hybrid (AR/SS) rotation.

${ }^{3}$ Annual ryegrass as a component of the annual ryegrass/bermudagrass (AR/BG) rotation.

${ }^{4}$ Sorghum-Sudan hybrid as a component of the AR/SS rotation.
} 
June. Later in the season, cows grazed warm-season pastures until the end of the lactation period in mid August, and continued to do so during the nonlactating period. Surplus growth from pasture was harvested as haylage to be fed to the respective herds during times when there was little pasture growth (i.e., January and February) or when transitioning from a cool-season to a warm-season pasture (i.e., late May and June).

Grazing and nongrazing activity of lactating cows was recorded daily; days spent grazing was calculated by difference [total DIM $-\mathrm{d}$ (or $1 / 2 \mathrm{~d}$ ) on the adjacent feeding area $-\mathrm{d}$ (or $1 / 2 \mathrm{~d}$ ) spent in shade paddocks]. During periods of forage shortage, cows were placed on an adjacent feeding area of 2.4 ha (1.2 ha for each FS group); this feeding area was not included in SR calculations. The areas were managed to avoid localized high concentrations of nutrients. To remove some of the excess nutrients in this feeding area, Ogle seed oats (Avena sativa L., a seeding rate of $69.0 \mathrm{~kg} / \mathrm{ha}$ ) or Trical 498 triticale (Triticale hexaploide Lart., a seeding rate of $50.0 \mathrm{~kg} / \mathrm{ha}$ ) were sown in March 2004. Stored forages were fed in this area, including the harvested production from the oats and triticale and haylage made from corresponding surplus growth on the grazing area. In addition, during periods of extreme heat and humidity (temperature-humidity index $\geq 86$, based on degrees Fahrenheit; White et al., 2002), cows were given access to wooded areas for shade. These wooded areas were rotationally managed to avoid extreme ground cover loss during the summer. Toward the end of lactation and starting in June of each year, cows from both stocking groups had access to the wooded areas for 22, 38, and $28 \mathrm{~d}$ during yr 1, 2, and 3, respectively. The grazing sequence and harvest management decisions were based on information collected during weekly pasture walks during the grazing season.

\section{Pasture Measures}

Estimates of herbage supply from pasture were recorded throughout the $3 \mathrm{yr}$, as outlined by Chamblee and Green (1995). Briefly, on each pasture walk, visual assessments, rising plate meter readings, and clippings to ground level (calibration measurements) were used to predict herbage mass (HM) of the cool-season pastures and bermudagrass. Pasture HM was assessed by 2 to 3 trained observers. Every 2 wk, 12 calibration quadrats $\left(0.25 \mathrm{~m}^{2}\right.$, usually 7 pregrazing and 5 postgrazing sites), at predetermined locations covering the range of HM present at the time, were assessed before the pasture walk. Before clipping, HM within each quadrat was visually scored, and standing and compressed stand height readings were collected using a rising plate meter, a $0.2-\mathrm{m}^{2}$ circular acrylic plate meter that exerted a pressure on the pasture canopy of 6.0 $\mathrm{kg} / \mathrm{m}^{2}$. Herbage mass was then clipped with the aid of a battery powered, sheep-shearing handpiece (Sunbeam, Botany, New South Wales, Australia). Clippings were taken to ground level and care was taken to avoid soil contamination.

Alternatively, sorghum Sudan pregrazing HM estimates were obtained by mowing 5 strips of approximately $7.0 \mathrm{~m}^{2}$ at a height of $5 \mathrm{~cm}$ above ground level with a sickle-type bar mower powered by a 4 -stroke Briggs \& Stratton single-speed engine, whereas postgrazing HM was obtained by clipping two $1.0-\mathrm{m}^{2}$ quadrats adjacent to each mowed site. Data obtained were used to estimate HM present, but only HM measurements from those paddocks to be grazed in the next 24-h period (pregrazing HM) and from those grazed in the previous 24-h period (postgrazing HM) were used to estimate DMI. Herbage allowance $(\mathbf{H A} ; \mathrm{kg}$ of DM offered/cow per d, estimates from ground level) was calculated as the product between pregrazing HM and grazing area divided by the number of cows. Paddocks not required for grazing were designated for mechanical harvesting and conserved mainly as wrapped silage or haylage.

Representative herbage samples were collected approximately twice a month during the grazing season. Herbage samples from pastures due to be grazed by each treatment group were hand-plucked to grazing height following a random transect (i.e., Kolver and Muller, 1998), bagged, and subsequently frozen in liquid N. Herbage samples were selectively hand-plucked to grazing height in an attempt to provide for a reasonable representation of the diet consumed by cows. These samples, along with samples of conserved forages and concentrate mix ingredients, were submitted to the North Carolina Forage Testing Laboratory (North Carolina Department of Agriculture, Raleigh) for analysis and assessments of nutritive value. Samples were dried in a forced-air oven at $60^{\circ} \mathrm{C}$ until constant weight was obtained and ground in a Wiley mill (Thomas Scientific, Swedesboro, NJ) to pass through a 1-mm sieve. Ground samples were analyzed for CP (Dumas combustion, Leco FP-428, Leco Corp., St. Joseph, MI) and ADF (wet chemistry, Ankom 200, Ankom Technology Corp., Fairport, NY, expressed with residual ash), whereas $\mathrm{NE}_{\mathrm{L}}$ concentration was determined using the Cornell regression equations as outlined by Mertens (1973).

\section{Intake, Milk Production, and Reproduction}

An herbage disappearance method was used to estimate herbage intake for each treatment group (Macoon et al., 2003). Based on the amounts of HM removed 
(the difference between pre- and postgrazing HM) at each grazing cycle, daily allocation of fresh herbage, and corresponding occupation time (grazing days) during the grazing season, estimates of grazed herbage DMI ( $\mathrm{kg}$ of $\mathrm{DM} / \mathrm{cow} / \mathrm{d}$ ) were obtained using to the following equation:

$$
\begin{gathered}
\text { Herbage DMI }=\Sigma \text { all grazing sources } \\
{[(\text { HMpre }- \text { HMpost }) \times a \times t],}
\end{gathered}
$$

where HMpre and HMpost are pre- and postgrazing $\mathrm{HM}(\mathrm{kg} \mathrm{DM} / \mathrm{ha}), a$ is the grazing area allocated $\left(\mathrm{m}^{2} /\right.$ cow), and $t$ is the proportion of time spent on each forage/crop rotation. This methodology provided an estimate of fresh herbage DMI for each treatment group.

All cows were milked twice daily at approximately 0600 and $1700 \mathrm{~h}$. Milk production data were collected by 2 methods (White et al., 2002). The first method consisted of milk weights recorded for each herd group at each milking (model FTT-710-5A, Accurate Metering Systems, Schaumburg, IL). However, complete lactation data were only available for the second and third year lactations because the measuring device was not available until the second half of the first lactation. The second method consisted of milk production data collected monthly for each cow under the DHIA protocols of Dairy Records Management Systems (Raleigh, NC). Individual milk samples collected monthly were analyzed at the regional DHIA laboratory (United DHIA, Blacksburg, VA) for fat, protein, and lactose concentrations, as well as SCC using a Fossomatic 360 (Foss Electronic, Slangerupgade, Denmark). These data were used for the estimation and statistical analysis of ECM and mature-equivalent milk, fat, and protein yields, for all 3 yr. Briefly, ECM determines the amount of energy in milk based upon milk yields and fat and protein concentrations, adjusted to $3.5 \%$ fat and $3.2 \%$ protein, and was calculated as follows: ECM, $\mathrm{kg}$ per cow $=(0.327 \times$ milk, $\mathrm{kg})+(12.95 \times$ fat, $\mathrm{kg})+(7.65 \times$ protein, kg) (Dairy Records Management Systems). To calculate mature-equivalent milk yield, fat yield, and protein yields, lactation was adjusted for DIM, milking frequency, calving month, location, and age relative to that of a mature cow (Schutz, 1994).

Cows were weighed and body condition was scored by an experienced observer using the 5 -point scale $(1=$ emaciated, $5=$ obese; in 0.25-point increments; Wildman et al., 1982). Breeding via detection of estrus and AI began in January and continued through March of each year. Tail-head paint was used to facilitate detection of estrus, and about $85 \%$ of cows were inseminated in response to a natural estrus. However, to ensure that each cow had at least one breeding opportunity, cows not observed in estrus by late February each year were synchronized as follows: GnRH on d 0, prostaglandin $\mathrm{F}_{2 \alpha}$ on $\mathrm{d} 7, \mathrm{GnRH}$ on $\mathrm{d} 9$, followed by timed AI the next day. Conception rates to first and subsequent services were calculated for each treatment group and breed.

\section{Economics}

Income over feed cost (IOFC) was selected as the measure for comparing the financial performance of the 2 groups. This indicator captures the major source of income on a specialized dairy farm, namely milk sales, and the major component of production cost, namely feed. This measure can be calculated from the data collected in the study, and the results are directly applicable to commercial farming. Milk income was estimated from kilograms of milk produced/cow per day and actual price received for milk; milk prices changed monthly. Daily feed costs were estimated from ration formulations, including an allowance for waste, in kilograms per cow per day of individual feedstuffs. Ingredient prices per kilogram for supplementary feeds were based on average market prices during the study period and held constant. Forage enterprise budgets created in 2006 provided for forage cost estimates. Income over feed cost was calculated per cow per day and per hectare of pasture in the farmlet.

Data on daily milk production were available for the complete 2004-2005 and 2005-2006 lactations. The number of cows milked in each group and total milk production for that group were recorded at each milking. Only cows producing saleable milk were included. Average daily milk production per cow milked was calculated for each month and for the whole lactation. By using daily milk data for each group and including only saleable milk, calculations of milk yields for economic considerations were not exactly the same as projected individual cow milk yields based on monthly DHIA samples.

Milk payments in the southeastern United States are made monthly and are based on milk volume. Milk value includes the weight and price of butterfat and the weight and price of skim milk. The fat concentration of the milk from each cow in each group was taken from the monthly DHI samples and a weighted average fat percentage was calculated monthly for each group. Milk fat and skim milk weights were calculated for each group, and actual milk fat and skim milk prices paid were used to calculate the corresponding milk income.

Daily feed costs were estimated from the ration formulations, which include an allowance for waste. Rations for all groups were developed using the Spartan Ration Balancing program (Spartan Software Laboratory, Department of Animal Science, Michigan State 
University, East Lansing). Forage and feed ingredient prices were held constant over the 2 lactations. Forage costs were based on the most recent North Carolina State University forage enterprise budgets. Estimated pasture cost was $\$ 11.02 / \mathrm{Mg}$ and haylage costs were estimated at $\$ 44.09 / \mathrm{Mg}$. These cost estimates are on an as-fed basis and include the full cost of producing and harvesting these crops, including operating expenses, labor, and annual charges on capital investments in machinery and equipment. Ingredient prices used in calculating supplementary feed costs were based on prevailing market prices. No charges were made for mixing and feeding the various rations because these costs were similar for both groups.

\section{Statistical Analyses}

Statistics on the effects of feeding strategy on preand postgrazing $\mathrm{HM}(\mathrm{kg} / \mathrm{ha})$, grazing interval (d), area offered daily $\left(\mathrm{m}^{2} / \mathrm{cow}\right)$, and nutritive value of fresh and conserved forage were performed using PROC MIXED of SAS (SAS Institute, 2002). The model for these variables included the fixed effects of treatment, year, treatment $\times$ year, and the random effect of paddock. Statistical analysis on time spent on an adjacent feeding area (d) was also performed using PROC MIXED (SAS Institute, 2002), but the model included the fixed effect of treatment and the random effect of year.

Individual yields of ECM and mature-equivalent milk, fat, and protein yields were analyzed using PROC MIXED (SAS Institute, 2002). The model for these variables included the fixed effects of treatment, breed, and treatment $\times$ breed, and the random effect of cow, a model similar to that of White et al. (2002) and Washburn et al. (2002). Treatment $\times$ breed interactions for ECM and mature-equivalent milk, fat, and protein yields were deemed nonsignificant $(P>0.05)$ and subsequently dropped from the model. The PDIFF option in SAS was used for comparison purposes among main breed effects. Categorical data including conception and pregnancy rates were evaluated using contingency Chisquared analyses comparing breeds and stocking rates. Data are presented as least squares means ( \pm SEM). Significance and trends were established at $P \leq 0.05$ and $P \leq 0.10$, respectively.

\section{RESULTS}

\section{Pasture Production, Quality, and Utilization}

Cows on HSR tended $(P=0.09)$ to spend more time on an adjacent feeding area (85 vs. $61 \mathrm{~d}$ ) and less time grazing (204 vs. 228 d, respectively; Table 2). Pre- and postgrazing HM of all pastures were similar among treatment groups (Table 3). Mean $\pm \mathrm{SE}$ weighted (for the proportion of time spent on each forage/crop rotation) pre- and postgrazing HM were $3,347 \pm 255.8$ and 1,861 $\pm 160.6 \mathrm{~kg}$ of $\mathrm{DM} / \mathrm{ha}$. Herbage allowances, weighed for the proportion of time spent on each forage/crop rotation, were 29.1 and $22.1 \mathrm{~kg}$ of $\mathrm{DM} /$ cow per $\mathrm{d}$ for cows on LSR and HSR, respectively. Grazing interval (i.e., the number of days between successive grazing events) did not differ between treatments (mean $\pm \mathrm{SE}$ : $23.6 \mathrm{~d} \pm 1.9 \mathrm{~d}$ ). Except for SS, areas offered daily to cows were greater $(P<0.10)$ for the LSR group; mean areas offered to cows on LSR were 16, 22, 7, and $40 \mathrm{~m}^{2}$ larger for $\mathrm{AR}$ from $\mathrm{AR} / \mathrm{SS}, \mathrm{AR}$ from $\mathrm{AR} / \mathrm{BG}, \mathrm{SS}$, and $\mathrm{BG}$, respectively.

The nutritive value of the fresh and conserved forages offered was similar for both groups, except for ADF concentrations from freshly grazed BG (29.6 vs. 26.3\% for LSR vs. HSR, respectively; $P<0.01$; Table 4). Amounts of conserved forage produced from the LSR area was $86 \%$ greater than that produced from the HSR farmlet (1,011 vs. $544 \mathrm{~kg}$ of $\mathrm{DM} /$ cow, respectively), with 43,32 , and $25 \%$ of conserved forage from annual ryegrass, tall fescue/white clover, and bermudagrass, respectively.

\section{Intake, Milk Production, and Reproduction}

Mean estimates of daily herbage DMI were (mean \pm SE) $9.0 \pm 0.19$ and $6.7 \pm 0.12 \mathrm{~kg}$ of $\mathrm{DM} /$ cow for cows on LSR and HSR, respectively; corresponding values for daily concentrate DMI were $6.30 \pm 0.08$ and 9.16 $\pm 0.10 \mathrm{~kg}$ of DM/cow. Body weights and BCS did not differ $(P>0.20)$ among treatment groups: (mean \pm $\mathrm{SE}) \mathrm{BW}$ and BCS were $485.5 \pm 16.7 \mathrm{~kg}$ and $2.70 \pm$ 0.018 , respectively. Daily milk production did not differ among treatment groups for yr 2 and 3 (results not shown), but overall lactation performance was greater $(P<0.05)$ for cows on HSR (Table 5$)$. Cows on HSR produced $10.8 \%$ more milk fat and $6.3 \%$ more protein than cows on LSR. Holstein cows produced the greatest $(P<0.001)$ amounts of mature-equivalent milk, but did not differ from crossbred cows in terms of ECM and mature-equivalent fat and protein yields. Interaction effects between treatment groups and breeds lacked significance.

Reproductive efficiency did not differ among FS (mean $\pm \mathrm{SE} ; 53.9 \pm 5.4 \%$ conception rate at first service, $55.3 \pm 5.7$ conception rate at all services, 87.7 $\pm 4.1 \%$ pregnancy rate), whereas breed differences in reproductive measures were reported (Table 5). Conception rates at first service and at all services, as well as pregnancy rates, were greater $(P<0.05)$ for Jersey and crossbred cows than for Holstein cows. Somatic cell count scores were similar among treatment groups and among breeds across the 3-yr study. 
Table 2. Monthly distribution of days spent on an adjacent feeding area by lactating dairy cows stocked at either a lesser stocking rate, lesser supplementation rate (LSR; 2.2 cows/ha) or a greater stocking rate, greater supplementation rate (HSR; 3.2 cows/ha) during a 3-yr trial

\begin{tabular}{|c|c|c|c|c|c|c|}
\hline \multirow[b]{3}{*}{ Month } & \multicolumn{6}{|c|}{ Year $^{1}$ and treatment } \\
\hline & \multicolumn{2}{|c|}{1} & \multicolumn{2}{|c|}{2} & \multicolumn{2}{|c|}{3} \\
\hline & LSR & HSR & LSR & HSR & LSR & HSR \\
\hline December & 11.5 & 11.0 & 5.0 & 24.0 & 19.5 & 19.5 \\
\hline January & 10.0 & 11.0 & 24.5 & 31.0 & 6.0 & 26.0 \\
\hline February & 28.0 & 28.0 & 10.5 & 21.0 & 28.0 & 28.0 \\
\hline March & 8.5 & 10.5 & 10.5 & 10.5 & 6.0 & 6.0 \\
\hline April & - & - & - & - & - & - \\
\hline May & 2.5 & 7.5 & - & - & - & - \\
\hline June & 5.0 & 7.0 & 5.5 & 12.5 & - & - \\
\hline July & - & - & - & - & - & - \\
\hline August & 1.5 & 1.0 & - & - & - & - \\
\hline Total $^{2}$ & 67.0 & 76.0 & 56.0 & 99.0 & 59.5 & 79.5 \\
\hline
\end{tabular}

${ }^{1}$ Year $1=2003-2004$; year $2=2004-2005$; year $3=2005-2006$.

${ }^{2}$ Total number of days on an adjacent feeding area: 60.8 and $84.8 \pm 5.6 \mathrm{~d}$ (mean $\pm \mathrm{SE}$ ) for LSR and HSR groups, respectively $(P=0.092)$.

\section{Economics}

Daily milk production was similar for both groups in yr 2 and 3, although measurable differences were observed in individual months (Table 6 ). The estimated fat concentration in milk was 0.240 and $0.203 \%$ greater for the HSR group in the 2004-2005 and 2005-2006 lactations, respectively, which had an effect on the value of the milk. Consequently, the milk income per day generated was slightly greater for the HSR group than for the LSR group.

As expected, average feed costs $(\$ /$ cow per d) were greater for the HSR group because more feed supplementation was required to meet the cows' nutritional requirements, and the cost of nutrients provided in the supplementary feed was greater than the equivalent cost from pasture. However, estimated daily feed costs were equivalent to only 26 and $28 \%$ of daily milk income for the LSR group for the 2004-2005 and 2005-2006 lactations, respectively. The corresponding numbers for the HSR group were 30 and $32 \%$. Overall, the estimated average IOFC/cow per day was somewhat lower for the cows that were stocked more heavily because the slight advantage in milk income was more than offset by the greater feed costs.

For the 2004-2005 lactation, the average daily IOFC for the LSR group was $\$ 5.01 /$ cow, compared with $\$ 4.82$ cow for the HSR cows. However, when IOFC was measured on a per hectare basis, the HSR cows had a substantial advantage, a $\$ 5.25$ difference/ha per day, or $46 \%$ greater. For the 2005-2006 lactation, the IOFC per cow were comparable, with the LSR cows generating $\$ 4.27 /$ cow and the HSR cows generating $\$ 4.24 /$ cow daily. On a per hectare basis, the advantage to the HSR group was $\$ 4.07$ or $48 \%$ greater. The generally lower IOFC figures for 2005-2006 were caused primarily by lower milk prices.

\section{DISCUSSION}

The primary aim of the trial was to examine the effect of FS upon animal performance, rather than to use SR to impose variation in grazing pressure. Two groups of cows were characterized by a unique combination of stocking rate and supplementation, a management strategy that used one level of each variable exclusively for each group. Consequently, the effects of stocking rate per se or supplementation level per se on animal and economic performance were not evaluated independently. Within this framework, data were collected on pasture production and utilization and animal performance. These results were extended to explore the economic consequences.

The alternative stocking rates were selected based on multiple considerations. One consideration was to be able to meet the minimum forage needs of the lactating cows from the allocated pasture area. A second consideration was to manage the pastures to achieve high levels of production and utilization under each system through the application of a common set of specified pasture management protocols. A third consideration was the maintenance of similar levels of total DMI in each group of cows.

\section{Pasture Production, Quality, and Utilization}

Autumn calving systems, such as the one in the current study, allow for grazing of high-quality, cool-season 
Table 3. Herbage mass (HM; $\mathrm{kg}$ of DM/ha), grazing interval (d), and area offered $\left(\mathrm{m}^{2}\right.$ per cow) to cows stocked at either a lesser stocking rate, lesser supplementation rate (LSR; 2.2 cows/ha) or a greater stocking rate, greater supplementation rate (HSR; 3.2 cows/ha) during a 3-yr trial

\begin{tabular}{|c|c|c|c|c|c|}
\hline \multirow[b]{3}{*}{ Item } & \multicolumn{4}{|c|}{ Treatment } & \multirow[b]{3}{*}{$P \leq$} \\
\hline & \multicolumn{2}{|c|}{ LSR } & \multicolumn{2}{|c|}{ HSR } & \\
\hline & Mean & SEM & Mean & SEM & \\
\hline \multicolumn{6}{|c|}{ Pregrazing $\mathrm{HM}, \mathrm{kg}$ of $\mathrm{DM} / \mathrm{ha}$} \\
\hline $\mathrm{AR}^{1}$ & 2,930 & 206 & 3,035 & 231 & 0.77 \\
\hline $\mathrm{AR}^{2}$ & 3,271 & 236 & 3,366 & 246 & 0.51 \\
\hline $\mathrm{SS}^{3}$ & 2,289 & 217 & 2,377 & 221 & 0.47 \\
\hline $\mathrm{BG}^{4}$ & 3,642 & 258 & 3,829 & 276 & 0.36 \\
\hline $\mathrm{TFWC}^{5}$ & 4,284 & 328 & 4,395 & 339 & 0.81 \\
\hline \multicolumn{6}{|c|}{ Postgrazing HM, $\mathrm{kg}$ of $\mathrm{DM} / \mathrm{ha}$} \\
\hline $\mathrm{AR}$ & 1,755 & 124 & 1,681 & 115 & 0.51 \\
\hline $\mathrm{AR}$ & 1,703 & 139 & 1,598 & 143 & 0.27 \\
\hline SS & 1,446 & 123 & 1,383 & 119 & 0.58 \\
\hline $\mathrm{BG}$ & 2,425 & 241 & 2,320 & 100 & 0.39 \\
\hline TFWC & 2,321 & 170 & 2,212 & 332 & 0.49 \\
\hline \multicolumn{6}{|c|}{ Grazing interval, d } \\
\hline $\mathrm{AR}$ & 26.2 & 2.0 & 24.3 & 1.5 & 0.29 \\
\hline $\mathrm{AR}$ & 22.4 & 1.6 & 22.1 & 1.5 & 0.82 \\
\hline SS & 22.1 & 2.3 & 20.3 & 2.6 & 0.77 \\
\hline BG & 25.5 & 2.6 & 26.2 & 2.3 & 0.51 \\
\hline \multicolumn{6}{|c|}{ Area offered daily, $\mathrm{m}^{2} / \mathrm{cow}$} \\
\hline $\mathrm{AR}$ & 98 & 7.7 & 82 & 5.3 & 0.09 \\
\hline $\mathrm{AR}$ & 104 & 9.8 & 82 & 5.3 & 0.05 \\
\hline SS & 110 & 12.1 & 103 & 10.5 & 0.19 \\
\hline $\mathrm{BG}$ & 105 & 13.6 & 65 & 6.4 & 0.01 \\
\hline
\end{tabular}

${ }^{1}$ Annual ryegrass as a component of the AR/SS rotation.

${ }^{2}$ Annual ryegrass as a component of the AR/BG rotation.

${ }^{3}$ Sorghum-Sudan hybrid as a component of the AR/SS rotation.

${ }^{4}$ Bermudagrass as a component of the AR/BG rotation.

${ }^{5}$ Tall fescue/white clover; TFWC was used primarily as stockpiled forage in late November and December to extend the autumn grazing season; values of grazing interval and area offered were not consistently recorded for this grazing source.

pastures in early to mid lactation, thus allowing periods of high nutrient requirement to match available forages of high nutritive value, along with the possibility of grazing during periods of cooler temperature. The latter aspect is particularly important for grazing systems in the southeastern United States. During autumn (October, November, December), cows were able to graze annual ryegrass almost entirely from the AR/

Table 4. Forage nutritive value (\% of DM), energy concentration (MJ of $\mathrm{NE}_{\mathrm{L}} / \mathrm{kg}$ of $\mathrm{DM}$ ), and amount of conserved forage (mean $\pm \mathrm{SE}$ ) from farmlets stocked at either a lesser (LSR; 2.2 cows/ha) or a greater (HSR; 3.2 cows/ha) stocking rate during a 3-yr trial

\begin{tabular}{|c|c|c|c|c|c|c|c|}
\hline Item $^{1}$ & $\mathrm{n}$ & \multicolumn{2}{|c|}{$\mathrm{CP}, \%$ of $\mathrm{DM}$} & \multicolumn{2}{|c|}{$\mathrm{ADF}, \%$ of $\mathrm{DM}$} & \multicolumn{2}{|c|}{$\mathrm{NE}_{\mathrm{L}}, \mathrm{MJ} / \mathrm{kg}$ of $\mathrm{DM}$} \\
\hline SS & 8 & $14.7 \pm 2.0$ & $14.9 \pm 2.3$ & $28.0 \pm 0.7$ & $27.4 \pm 1.8$ & $6.2 \pm 0.1$ & $6.2 \pm 0.1$ \\
\hline BG & 8 & $19.3 \pm 1.2$ & $19.5 \pm 2.0$ & $29.6^{\mathrm{a}} \pm 0.7$ & $26.3^{\mathrm{b}} \pm 0.8$ & $6.1 \pm 0.1$ & $6.2 \pm 0.1$ \\
\hline TFWC & 12 & $15.5 \pm 1.5$ & $14.6 \pm 0.9$ & $30.0 \pm 1.3$ & $29.7 \pm 1.3$ & $5.9 \pm 0.2$ & $5.9 \pm 0.2$ \\
\hline TFWC & 6 & $11.6 \pm 1.0$ & $12.1 \pm 1.4$ & $37.3 \pm 1.0$ & $36.0 \pm 1.2$ & $4.8 \pm 0.1$ & $4.9 \pm 0.1$ \\
\hline Conserved forages produced & & LSR & HSR & & & & \\
\hline $\mathrm{kg}$ of $\mathrm{DM} / \mathrm{yr}$ & & 35,077 & 19,091 & & & & \\
\hline $\mathrm{kg}$ of $\mathrm{DM} /$ cow per $\mathrm{yr}$ & & 1,011 & 544 & & & & \\
\hline
\end{tabular}

${ }^{\mathrm{a}, \mathrm{b}}$ Freshly grazed bermudagrass ADF concentration was greater $(P=0.006)$ for LSR.

${ }^{1} \mathrm{AR}=$ annual ryegrass; $\mathrm{SS}=$ sorghum-Sudan hybrid; $\mathrm{BG}=$ bermudagrass; TFWC $=$ tall fescue/white clover. 
Table 5. Milk production and reproductive performance from cows stocked at either a lesser stocking rate, lesser supplementation rate (LSR; 2.2 cows/ha) or a greater stocking rate, greater supplementation rate (HSR; 3.2 cows/ha) during a 3-yr trial

\begin{tabular}{|c|c|c|c|c|c|c|c|c|c|}
\hline \multirow[b]{2}{*}{ Item } & \multicolumn{2}{|c|}{ Treatment } & \multirow[b]{2}{*}{ SEM } & \multirow[b]{2}{*}{$P \leq$} & \multicolumn{3}{|c|}{ Breed } & \multirow[b]{2}{*}{ SEM } & \multirow[b]{2}{*}{$P \leq$} \\
\hline & LSR & HSR & & & Holstein & Jersey & Crossbred & & \\
\hline MEq milk, ${ }^{2} \mathrm{~kg}$ & 6,011 & 6,440 & 71 & 0.010 & $7,051^{\mathrm{a}}$ & $5,369^{\mathrm{b}}$ & $6,253^{\mathrm{c}}$ & 214 & $<0.001$ \\
\hline $\mathrm{MEq} \mathrm{fat},{ }^{3} \mathrm{~kg}$ & 203 & 225 & 2.4 & 0.009 & $227^{\mathrm{a}}$ & $198^{\mathrm{b}}$ & $216^{\mathrm{ab}}$ & 7.3 & 0.051 \\
\hline MEq protein,$^{3} \mathrm{~kg}$ & 190 & 202 & 1.6 & 0.006 & $212^{\mathrm{a}}$ & $177^{\mathrm{b}}$ & $199^{\mathrm{a}}$ & 6.4 & 0.006 \\
\hline \multicolumn{10}{|l|}{ Reproduction } \\
\hline 90-d pregnancy, \% & 75.4 & 74.6 & 4.7 & 0.82 & $61.4^{\mathrm{a}}$ & $77.2^{\mathrm{b}}$ & $86.4^{\mathrm{b}}$ & 5.2 & $<0.05^{5}$ \\
\hline SCS & 3.41 & 3.30 & 0.13 & 0.14 & 3.38 & 3.28 & 3.41 & 0.12 & NS \\
\hline
\end{tabular}

${ }^{\mathrm{a}-\mathrm{c}}$ Means in the same row with different letters differ $(P \leq 0.05)$. Treatment by breed effects were not significant (NS; $\left.P>0.15\right)$.

${ }^{1} \mathrm{ECM}=(0.327 \times$ milk, $\mathrm{kg})+(12.95 \times$ fat, $\mathrm{kg})+(7.65 \times$ protein, $\mathrm{kg}) ;$ Dairy Records Management Systems (Raleigh, NC).

${ }^{2}$ Mature-equivalent milk yield; lactation adjusted for DIM, milking frequency, calving season, location, and age relative to that of a mature cow (Schutz, 1994).

${ }^{3}$ Mature-equivalent fat and protein yields (Schutz, 1994).

${ }^{4}$ Crossbred $>$ average of $\mathrm{J}$ and $\mathrm{H}, P<0.05$; J vs. H, NS via Chi square. J $=$ Jersey; $\mathrm{H}=$ Holstein.

${ }^{5} \mathrm{~J}>\mathrm{H}, P<0.05$; and Crossbred $>$ average of $\mathrm{J}$ and $\mathrm{H}, P<0.05$ via Chi square.

SS rotation. Annual ryegrass from the AR/SS rotation provided for 61 and $67 \%$ of the total AR grazing days for cows on the LSR and HSR groups. Compared with the proportional grazing days preassigned to each forage/crop rotation ( $50 \%$ on $\mathrm{AR} / \mathrm{SS}, 20 \%$ on $\mathrm{AR} / \mathrm{BG}$, $30 \%$ on TFWC), actual grazing days were 54.6, 22.2, and $23.2 \%$ for cows on the LSR group, and 52.9, 20.7, and $26.4 \%$ for cows on the HSR group, respectively.

Although original target values for pre- and postgrazing $\mathrm{HM}$ of $\mathrm{AR}$ were approximately 2,800 and 1,600 kg of $\mathrm{DM} /$ ha, respectively, actual values were somewhat greater, particularly those of $\mathrm{AR}$ as a component of the AR/BG rotation (Table 3). This component was often grazed after the AR from the AR/SS rotation because of the shorter time required from planting to grazing by the conventional tillage rotation. The lack of significance between postgrazing HM was seemingly due to the greater supplementation rate for cows on HSR along with a chosen SR that did not impose extreme variation in grazing pressure. Pre- and postgrazing HM values from BG were consistent with those reported by Fontaneli et al. (2005) for BG summer grazing in Florida. The tall fescue/white clover pasture provided for a mean of 50 grazing days across treatment groups, $43 \%$ of which was offered as stockpiled fescue during the months of December through February, which explains the high pre- and postgrazing HM reported for this grazing source. Tall fescue was used primarily as a stockpiled grazing source to extend the grazing season into the winter, due to the relatively high autumn growth rate and the ability to resist, to some extent, increasing declines in nutritive value as forage accumu- lates relative to other cool season forages (Poore et al., 2000).

Nutritive value from fresh herbage was minimally altered by increasing stocking rate; the subtle differences between postgrazing HM were not large enough to alter the chemical composition of the diets selected by the grazing cows (Table 4). Increasing SR has resulted in similar (O'Donovan et al., 2004; Kennedy et al., 2007) or improved nutritive value offered to lactating dairy cows, particularly from reduced ADF and NDF concentrations and increased OM digestibility (Macdonald et al., 2008) from ryegrass-based pastures. Similarly, increasing SR resulted in similar nutritive values being offered to lactating cows grazing a bermudagrass-based pasture (Fike et al., 2003).

The need for cows on HSR to spend more time on an adjacent feeding area, as opposed to grazing, needs to be considered before implementing the design and layout of a grazing system in the region. Year-round grazing in eastern North Carolina is not possible because of limited growth in winter, during short periods in which pasture damage may occur after heavy rainfall, and during transition periods from cool- to warm-season pastures. Although the adjacent feeding areas were also managed rotationally, the higher stocking density during non-grazing periods may cause severe overloading of nutrients. Nutrient removal from mechanically harvesting excess spring forage growth was used as a means to reduce the buildup of nutrients from those areas; oats and triticale were chosen for their potential to remove excess nutrients due to lower $\mathrm{N}$ to phosphorus $(\mathrm{P})$ ratios and greater $\mathrm{P}$ concentration in stems 
Table 6. Milk production ( $\mathrm{kg} /$ cow per d), milk sales (US $\$ /$ cow per d), feed cost (US\$/cow per d), and income over feed cost (IOFC; US $\$ /$ cow per d) from cows stocked at either a lesser stocking rate, lesser supplementation rate (LSR; 2.2 cows/ha) or a greater stocking rate, greater supplementation rate (HSR; 3.2 cows/ha)

\begin{tabular}{|c|c|c|c|c|c|c|c|c|c|c|c|c|}
\hline \multirow[b]{2}{*}{ Item } & \multicolumn{4}{|c|}{ LSR } & \multicolumn{4}{|c|}{ HSR } & \multicolumn{4}{|c|}{ LSR - HSR } \\
\hline & Milk & $\begin{array}{l}\text { Milk } \\
\text { sales }\end{array}$ & $\begin{array}{l}\text { Feed } \\
\text { cost }\end{array}$ & IOFC & Milk & $\begin{array}{l}\text { Milk } \\
\text { sales }\end{array}$ & $\begin{array}{c}\text { Feed } \\
\text { cost }\end{array}$ & IOFC & Milk & $\begin{array}{l}\text { Milk } \\
\text { sales }\end{array}$ & $\begin{array}{l}\text { Feed } \\
\text { cost }\end{array}$ & IOFC \\
\hline \multicolumn{13}{|c|}{ 2004-2005 lactation } \\
\hline November 2004 & 27.3 & 9.39 & 1.72 & 7.67 & 26.3 & 9.75 & 2.04 & 7.71 & 0.92 & -0.36 & -0.32 & -0.04 \\
\hline December 2004 & 22.1 & 7.45 & 1.82 & 5.63 & 23.1 & 7.79 & 2.38 & 5.41 & -1.06 & -0.33 & -0.56 & 0.23 \\
\hline January 2005 & 20.5 & 7.91 & 2.33 & 5.58 & 20.1 & 7.90 & 2.49 & 5.41 & 0.39 & 0.01 & -0.16 & 0.16 \\
\hline February 2005 & 21.1 & 7.05 & 1.92 & 5.13 & 21.1 & 7.36 & 2.36 & 5.00 & -0.01 & -0.31 & -0.44 & 0.12 \\
\hline March 2005 & 19.4 & 6.98 & 1.94 & 5.04 & 19.1 & 6.64 & 2.21 & 4.43 & 0.32 & 0.34 & -0.27 & 0.61 \\
\hline April 2005 & 22.5 & 7.31 & 1.62 & 5.70 & 21.7 & 7.39 & 1.89 & 5.51 & 0.74 & -0.08 & -0.27 & 0.19 \\
\hline May 2005 & 18.4 & 6.02 & 1.55 & 4.47 & 17.4 & 5.86 & 1.78 & 4.08 & 1.07 & 0.16 & -0.23 & 0.39 \\
\hline June 2005 & 14.1 & 4.27 & 1.75 & 2.52 & 14.3 & 4.41 & 1.97 & 2.44 & -0.18 & -0.15 & -0.22 & 0.08 \\
\hline July 2005 & 14.3 & 4.92 & 1.54 & 3.38 & 15.1 & 5.27 & 1.86 & 3.41 & -0.78 & -0.35 & -0.31 & -0.03 \\
\hline Mean & 20.0 & 6.81 & 1.80 & 5.01 & 19.8 & 6.93 & 2.11 & 4.82 & 0.16 & -0.12 & -0.31 & 0.19 \\
\hline Mean/ha & 45.7 & 15.60 & 4.12 & 11.48 & 68.7 & 24.04 & 7.31 & 16.72 & -22.97 & -8.44 & -3.19 & -5.25 \\
\hline \multicolumn{13}{|c|}{ 2005-2006 lactation } \\
\hline November 2005 & 25.5 & 8.63 & 1.62 & 7.01 & 20.9 & 7.37 & 1.91 & 5.46 & 4.54 & 1.26 & -0.29 & 1.55 \\
\hline December 2005 & 19.5 & 6.54 & 1.62 & 4.92 & 20.5 & 6.90 & 1.91 & 4.99 & -1.00 & -0.36 & -0.29 & -0.07 \\
\hline January 2006 & 20.4 & 6.78 & 1.71 & 5.07 & 21.1 & 7.11 & 2.25 & 4.86 & -0.69 & -0.33 & -0.54 & 0.20 \\
\hline February 2006 & 17.4 & 5.60 & 2.08 & 3.51 & 19.3 & 6.40 & 2.40 & 3.99 & -1.86 & -0.80 & -0.32 & -0.48 \\
\hline March 2006 & 19.7 & 6.01 & 1.67 & 4.34 & 21.7 & 6.50 & 1.93 & 4.57 & -1.96 & -0.49 & -0.25 & -0.24 \\
\hline April 2006 & 21.7 & 5.98 & 1.57 & 4.41 & 22.5 & 6.30 & 1.83 & 4.46 & -0.82 & -0.32 & -0.27 & -0.06 \\
\hline May 2006 & 18.4 & 5.09 & 1.57 & 3.52 & 19.5 & 5.53 & 1.86 & 3.67 & -1.15 & -0.44 & -0.29 & -0.15 \\
\hline June 2006 & 16.0 & 4.55 & 1.48 & 3.07 & 17.2 & 4.89 & 1.76 & 3.13 & -1.20 & -0.35 & -0.29 & -0.06 \\
\hline July 2006 & 13.4 & 3.99 & 1.43 & 2.56 & 15.1 & 4.75 & 1.72 & 3.03 & -1.70 & -0.76 & -0.29 & -0.47 \\
\hline Mean & 19.1 & 5.91 & 1.64 & 4.27 & 19.8 & 6.19 & 1.95 & 4.24 & -0.65 & -0.29 & -0.31 & 0.02 \\
\hline Mean/ha & 37.7 & 11.67 & 3.24 & 8.43 & 58.2 & 18.24 & 5.75 & 12.49 & -20.44 & -6.58 & -2.51 & -4.07 \\
\hline \multicolumn{13}{|c|}{ 2004-2005 and 2005-2006 lactations } \\
\hline Mean & 19.5 & 6.36 & 1.72 & 4.64 & 19.8 & 6.56 & 2.03 & 4.53 & -0.25 & -0.20 & -0.31 & 0.11 \\
\hline Mean/ha & 41.7 & 13.63 & 3.68 & 9.95 & 63.4 & 21.14 & 6.53 & 14.61 & -21.70 & -7.51 & -2.85 & -4.66 \\
\hline
\end{tabular}


relative to that of other cool-season forages (Pederson et al., 2002).

\section{Intake, Milk Production, and Reproduction}

Differences in stocking rates created variation in the daily herbage allowance per cow. As measured from ground level, the greater SR resulted in a decreased daily herbage allowance (22.1 vs. $29.1 \mathrm{~kg}$ herbage DM/ cow), consistent with a $35 \%$ decrease in daily herbage intake from pasture (6.7 vs. $9.0 \mathrm{~kg}$ herbage DM consumed per cow). Corresponding intakes of supplemental concentrate (imposed by amounts offered) were 9.2 and $6.3 \mathrm{~kg}$ of $\mathrm{DM} /$ cow, a $46 \%$ increase for cows in the HSR group, resulting in similar total DM intakes (15.3 and $15.8 \mathrm{~kg}$ of DM intake for cows on LSR and HSR, respectively). Consumption of conserved forage occurred only sporadically, at times when pastures were not accessible; both groups were offered similar amounts and absolute values were not considered herein. Consumption of fresh herbage from grazing and concentrates from those offered twice daily in the barn resulted in forage:concentrate ratios of 59:41 and 42:58 for diets consumed by cows on LSR and HSR, respectively, resulting in greater yields of milk fat and protein for cows on HSR (DHIA data, Table 5). Replacing pasture with supplements in an effort to improve or maintain nutritive value, rather than to increase total energy consumed, does not necessarily lead to improved daily milk production per cow (Carruthers et al., 1997; Roche and Holmes, 2007). However, at times of herbage shortage or declining nutritive value (i.e., late spring for AR during late lactation), greater levels of supplementation resulted in increased total energy consumed, and hence, in enhanced whole-lactation milk solids production of cows on HSR.

Under the present trial conditions, milk and milk solids yield per hectare were largely driven by stocking rate. A simple calculation (individual performance $\times$ cows carried per ha) indicated a greater lactation performance (for all performance variables measured) per hectare for cows on the HSR group, consistent with findings reported previously (Fales et al., 1995). Given the feasibility of feeding supplementary sources (concentrates and conserved forage), farmers can increase the number of lactating cows per unit area (at least within the range of SR tested herein) while maintaining satisfactory per cow performance.

Mean BW and BCS remained largely unaffected by feeding strategy. In early lactation, when most of the body condition scoring occurred, rate of BCS loss was largely due to physiological, rather than nutritional, causes; genetically driven body tissue mobilization after calving largely exceeds nutritional drivers (Roche and Holmes, 2007). Consistent with the BW and BCS findings, reproduction efficiency was not altered by feeding strategy. Our findings are consistent with those reported elsewhere (Dillon et al., 1995; Washburn et al., 2002; Macdonald et al., 2008; Baudracco et al., 2011).

Maintaining a satisfactory reproductive performance is critical to the success of a seasonal calving system, where time of breeding often coincides with peak lactation and negative energy balance from early lactation (Auldist et al., 2007). Jersey and $\mathrm{H} \times \mathrm{J}$ cows had greater conception rates at first service and over all services, and exhibited greater pregnancy rates over the entire breeding season than $\mathrm{H}$ cows. These results are consistent with those reported by Washburn et al. (2002) for $\mathrm{H}$ and $\mathrm{J}$ cows grazing in North Carolina (51.4 and $59.0 \%$ first-service conception, 54.5 and $60.2 \%$ all services conception, 63.0 and $80.5 \%$ pregnancy at $75 \mathrm{~d}$, respectively). Our results also concur with those reported by Auldist et al. (2007) for $\mathrm{H}$ and $\mathrm{H} \times \mathrm{J}$ cows under a seasonal calving system in Australia (42 and 52\% first-service conception, 54 and $68 \%$ conception at 6 wk, 78 and $86 \%$ conception at $14 \mathrm{wk}$, respectively). The conception rate values among the $\mathrm{J}$ cows in the current study were lower than expected in the first year of the study, most likely because the cows were moved from a confinement-feeding system at a different location in early lactation and had to adapt to the pasture-based system shortly before the breeding season commenced. As a result, conception rate for J cows was lower relative to the 3-yr mean value, and may not precisely reflect long-term reproductive success of J cows.

\section{Economics}

The IOFC estimates based on actual daily milk production data showed that similar levels of milk production were obtained under both feeding strategies, but the butterfat percentage was lower for the LSR group, which reduced the unit value of the milk and caused daily milk income per cow to be slightly lower (Table 6). Supplementary feed costs were greater for the cows stocked at higher rates but the effect on daily IOFC/ cow was relatively small. The advantage in IOFC to LSR was $4 \%$ and $<1 \%$ for the 2004-2005 and 2005-2006 lactations, respectively. However, a substantial advantage was found in IOFC margin per hectare in favor of the HSR group, of over 46\% for the 2004-2005 lactation and $48 \%$ for the 2005-2006 lactation.

These results suggest that a substantial financial advantage can be attained by adopting a greater stocking rate under the relative milk prices and feed costs reported at the time of this trial. Dairy farmers who might benefit include those with limited land or those seeking to expand cow numbers without a correspond- 
ing increase in land area. However, IOFC provides only a partial economic analysis and many other factors affect profitability and financial feasibility. An investigation of the effects of alternative stocking rates on profitability and financial feasibility should include a complete evaluation of all relevant costs and returns. It would be prudent to evaluate the sensitivity of the results to different milk prices and feed cost scenarios. In addition, the environmental impact and effects on stand life of greater stocking rates should be considered. Finally, it should be noted that published farm financial data show wide variation in financial performance among farms with any particular type of dairy farming system, and comparable variation among grazing farms with similar pasture management strategies could be expected.

\section{CONCLUSIONS}

The greater stocking rate, greater supplementation feeding strategy resulted in greater yields of matureequivalent milk, milk fat, and milk protein relative to the lesser stocking rate, lesser supplementation strategy. Consequently, under the trial conditions described, milk and milk solids yield per hectare were largely driven by stocking rate. In terms of reproductive efficiency and long-term sustainability, Jersey and Holstein $x$ Jersey crossbred cows appear to be more suited than pure Holstein cows for use in seasonal-calving systems under grazing conditions. We found minimal differences in long-term pasture production and utilization, which demonstrates that greater levels of supplementation did not affect pasture performance. The greater stocking rate was associated with additional supplemental concentrate, supplemental forage, and nongrazing time away from grazing paddocks, all of which imply a greater expenditure for this feeding strategy. However, similar reproductive efficiencies, overall greater lactation performance per cow, and increased productivity per unit of land favored the more intensive feeding strategy tested under the economic conditions that existed during the trial. For situations with substantially different economic conditions, including prices received for milk or costs of supplemental concentrates and stored forages, the optimal stocking rate could be expected to vary.

\section{ACKNOWLEDGMENTS}

The authors acknowledge the Southern Region Sustainable Agriculture Research and Education Program of the USDA (Griffin, GA), the North Carolina Agricultural Research Service (Raleigh, NC), the North Carolina Cooperative Extension Service (Raleigh, NC), and the North Carolina Department of Agriculture and Consumer Services (Raleigh, NC) for funding and research support. The authors thank P. Thompson and J. Garrett (North Carolina State University) for their invaluable technical assistance, A. Meier (CEFS Dairy Unit manager) and the staff at the CEFS Dairy unit for their care of the experimental animals and assistance with sample collection, and C. Hoogendoorn and F. Li (AgResearch Limited, Grasslands Research Centre, Palmerston North, New Zealand) for their valuable comments on a previous version of the manuscript.

\section{REFERENCES}

Abberton, M. T., A. H. Marshall, M. W. Humphreys, J. H. Macduff, R. P. Collins, and C. L. Marley. 2008. Genetic improvement of forage species to reduce the environmental impact of temperate livestock grazing systems. Adv. Agron. 98:311-355.

Auldist, M. J., M. F. S. Pyman, C. Grainger, and K. L. Macmillan. 2007. Comparative reproductive performance and early lactation productivity of Jersey $\times$ Holstein cows in predominantly Holstein herds in a pasture-based dairying system. J. Dairy Sci. 90:48564862.

Bargo, F., L. D. Muller, E. S. Kolver, and J. E. Delahoy. 2003. Invited review: Production and digestion of supplemented dairy cows on pasture. J. Dairy Sci. 86:1-42.

Bargo, F., L. D. Muller, G. A. Varga, J. E. Delahoy, and T. W. Cassidy. 2002. Ruminal digestion and fermentation of high-producing dairy cows with three different feeding systems combining pasture and total mixed rations. J. Dairy Sci. 85:2964-2973.

Barnhill, W. L. 1974. Soil Survey of Wayne County, North Carolina USDA-SCS. US Government Printing Office, Washington, DC.

Baudracco, J., N. Lopez-Villalobos, C. Holmes, and K. Macdonald. 2010. Effects of stocking rate, supplementation, genotype and their interactions on grazing dairy systems: A review. N. Z. J. Agric. Res. 53:109-133.

Baudracco, J., N. Lopez-Villalobos, L. A. Romero, D. Scandolo, M. Maciel, E. A. Comeron, C. Holmes, and T. N. Barry. 2011. Effects of stocking rate on pasture production, milk production and reproduction of supplemented crossbred Holstein-Jersey dairy cows grazing lucerne pasture. Anim. Feed Sci. Technol. 168:131-143.

Benson, G. A., S. P. Washburn, and J. T. Green Jr. 2006. Some Preliminary Results from the CEFS Dairy Grazing Project. Pages 75-77 in Proc. 6th Mid-Atlantic Dairy Grazing Conference, Goldsboro, NC. Accessed Dec. 12, 2011. http://www.cefs.ncsu.edu/publications/dairyconferenceproceedings/20somepreliminaryresultsbe nson.pdf.

Carruthers, V. R., P. G. Neil, and D. E. Dalley. 1997. Effect of altering the non-structural: Structural carbohydrate ratio in a pasture diet on milk production and ruminal metabolites in cows in early and late lactation. Anim. Sci. 64:393-402.

Chamblee, D., and J. T. Green Jr. 1995. Production and Utilization of Pastures and Forages in North Carolina. Tech. Bull. 305:154-155. North Carolina Agricultural Research Service, North Carolina State University, Raleigh.

Dillon, P., S. Crosse, G. Stakelum, and F. Flynn. 1995. The effect of calving date and stocking rate on the performance of springcalving dairy cows. Grass Forage Sci. 50:286-299.

Dillon, P., J. R. Roche, L. Shalloo, and B. Horan. 2005. Optimising financial returns from grazing in temperate pastures. Pages 131-147 in Utilisation of Grazed Grass in Temperate Animal Systems. Workshop of the 20th International Grassland Congress. J. J. Murphy, ed. Wageningen Academic Publishers, Wageningen, the Netherlands.

Fales, S. L., L. D. Muller, S. A. Ford, M. O'Sullivan, R. J. Hoover, L. A. Holden, L. E. Lanyon, and D. R. Buckmaster. 1995. Stocking rate affects production and profitability in a rotationally grazed pasture system. J. Prod. Agric. 8:88-96. 
Fike, J. H., C. R. Staples, L. E. Sollenberger, B. Macoon, and J. E. Moore. 2003. Pasture forages, supplementation rate, and stocking rate effects on dairy cow performance. J. Dairy Sci. 86:1268-1281.

Fontaneli, R. S., L. E. Sollenberger, R. C. Littell, and C. R. Staples. 2005. Performance of lactating dairy cows managed on pasturebased or in freestall barn-feeding systems. J. Dairy Sci. 88:12641276.

Kennedy, E., M. O'Donovan, F. P. O'Mara, J. P. Murphy, and L. Delaby. 2007. The effect of early-lactation feeding strategy on the lactation performance of spring-calving dairy cows. J. Dairy Sci. 90:3060-3070.

King, C. K. 1997. Simulation of the effects of dairy farm design on the productivity and profitability of grazing dairy farms in North Carolina. MS Thesis. North Carolina State University, Raleigh.

Kolver, E. S., and L. D. Muller. 1998. Performance and nutrient intake of high producing Holstein cows consuming pasture or a total mixed ration. J. Dairy Sci. 81:1403-1411.

Macdonald, K. A., J. W. Penno, J. A. S. Lancaster, and J. R. Roche. 2008. Effect of stocking rate on pasture production, milk production, and reproduction of dairy cows in pasture-based systems. J. Dairy Sci. 91:2151-2163.

Macoon, B., L. E. Sollenberger, J. E. Moore, C. R. Staples, J. H. Fike, and K. M. Portier. 2003. Comparison of three techniques for estimating the forage intake of lactating dairy cows on pasture. J. Anim. Sci. 81:2357-2366.

Mertens, D. R. 1973. Application of theoretical mathematical models to cell wall digestion and forage intake in ruminants. PhD Diss. Cornell Univ., Ithaca, NY.

O'Donovan, M., L. Delaby, and J. L. Peyraud. 2004. Effect of time of initial grazing date and subsequent stocking rate on pasture production and dairy cow performance. Anim. Res. 53:489-502.

Pederson, G. A., G. E. Brink, and T. E. Fairbrother. 2002. Nutrient uptake in plant parts of sixteen forages fertilized with poultry litter: Nitrogen, phosphorus, potassium, copper, and zinc. Agron. J. $94: 895-904$.

Poore, M. H., G. A. Benson, M. E. Scott, and J. T. Green Jr. 2000. Production and use of stockpiled fescue to reduce beef cattle production costs. J. Anim. Sci. 79:1-11.

Roche, J. R., and C. W. Holmes. 2007. Milk production, body condition score and reproduction responses to supplementation in grazing dairy cows. Pages 253-267 in Proc. South Island Dairy Event. Lincoln University, Christchurch, New Zealand.

SAS Institute. 2002. User's Guide Version 9.1: Statistics. SAS Institute Inc., Cary, NC.

Schutz, M. M. 1994. Age-season standardization for yield traits. Animal Improvement Programs Laboratory, ARS-USDA, Beltsville,
MD. Accessed June 30, 2010. http://aipl.arsusda.gov/reference/ ageseason.htm.

Scott, H. D., S. Phelps, and R. H. Pleasants. 2003. Spatial Distribution and Management of the Soils in Wayne County, North Carolina. Publication 03-01, Agribusiness Center, Mount Olive College, NC.

Soriano, F. D., C. E. Polan, and C. N. Miller. 2001. Supplementing pasture to lactating Holsteins fed a total mixed ration diet. J. Dairy Sci. 84:2460-2468.

Vibart, R. E., S. P. Washburn, G. A. Benson, and J. T. Green Jr. 2009a. Effects of stocking rate and supplementation on lactation and reproduction in pasture-based dairy systems in Eastern North Carolina. J. Dairy Sci. 92(Suppl. 1):575. (Abstr.)

Vibart, R. E., S. P. Washburn, G. A. Benson, and J. T. Green Jr. $2009 \mathrm{~b}$. Effects of stocking rate and supplementation on pasture quality, production, and utilization in pasture-based dairy systems in Eastern North Carolina. J. Dairy Sci. 92(Suppl. 1):223. (Abstr.)

Washburn, S. P., G. A. Benson, J. T. Green Jr., and C. M. Williams. 2006. Effects of stocking rate and breed on milk production and reproduction in a pasture-based dairy system. Pages 79-82 in Proceedings of the 6th Mid-Atlantic Dairy Grazing Conference. Goldsboro, NC. Accessed Dec. 12, 2011. http://www.cefs.ncsu. edu/publications/dairyconferenceproceedings/21effectsofstockingr atewashburn.pdf.

Washburn, S. P., S. L. White, J. T. Green Jr., and G. A. Benson. 2002 Reproduction, mastitis, and body condition of seasonally calved Holstein and Jersey cows in confinement or pasture systems. J. Dairy Sci. 85:105-111.

Welsh, R., and K. Ingram. 1997. Systems Research Methods Handbook. A handbook prepared in 1997 for the Southern Region Sustainable Research and Education Program. Griffin, GA.

White, S. L., G. A. Benson, S. P. Washburn, and J. T. Green Jr. 2002. Milk production and economic measures in confinement or pasture systems using seasonally calved Holstein and Jersey cows. J. Dairy Sci. 85:95-104

White, S. L., R. E. Sheffield, S. P. Washburn, L. D. King, and J. T. Green Jr. 2001. Spatial and time distribution of dairy cattle excreta in an intensive pasture system. J. Environ. Qual. 30:21802187

Wildman, E. E., G. M. Jones, P. E. Wagner, R. L. Boman, H. F. Troutt, and T. N. Lesch. 1982. A dairy cow body condition scoring system and its relationship to selected production characteristics. J. Dairy Sci. 65:495-501. 